\title{
MIĘDZY NONKONFORMIZMEM A KONFORMIZMEM, CZYLI O POSTAWACH SPRZECIWU WOBEC SYSTEMU AUTORYTARNEGO NA PRZYKLADACH ŻYCIORYSÓW PRZYWÓDCÓW ROLNICZEJ „SOLIDARNOŚCI” WOJEWÓDZTWA BIALOSTOCKIEGO Z LAT 80. XX WIEKU ${ }^{1}$
}

\author{
DOI: $10.15290 /$ sp.2020.28.08
}

\begin{abstract}
Abstrakt. Na podstawie życiorysów trzech działaczy opozycyjnych pochodzących ze środowisk wiejskich Białostocczyzny artykuł opisuje różne strategie zachowania jednostek nonkonformistycznych funkcjonujących w warunkach systemu autorytarnego. Podstawą opisu są pojęcia konformizmu/nonkonformizmu zdefiniowane na gruncie socjologii, psychologii społecznej i filozofii.
\end{abstract}

Słowa kluczowe: nonkonformizm, konformizm, koniunkturalizm, postawy społeczne, jednostka, opozycja, autorytaryzm, komunizm, województwo białostockie

\begin{abstract}
The article delves into various attitudes expressed by nonconformist individuals functioning under an authoritarian regime, as exemplified by three opposition activists from the rural areas surrounding Białystok. The research is based on the concepts of conformity and nonconformity as defined by sociology, social psychology and philosophy.
\end{abstract}

Key words: nonconformity, conformity, opportunism, social attitudes, person, opposition, authoritarianism, communism, Podlasie region

Coraz dłuższa perspektywa dzieląca historyków od upadku komunizmu w Polsce powinna pozwalać na swobodny ogląd i pozbawioną emocji, naukową ocenę postaw i zachowań ${ }^{2}$ polskiego społeczeństwa $\mathrm{w}$ okresie niespełna 45 lat funkcjonowania tego systemu politycznego. Jednak w dysku-

1 Artykuł powstał w oparciu o referat pt. Przywódcy rolniczej "Solidarności" na Białostocczyźnie - drogi chłopskich (non)konformistów do działalności opozycyjnej wygłoszony podczas ogólnopolskiej konferencji naukowej pt. Ruch ludowy i polska wieś wobec Niepodległości, Supraśl-Nidzica, 19-21 IX 2018 r., zorganizowanej przez Instytut Pamięci Narodowej.

2 Definicję pojęcia postawy jednostki przyjąłem za Stefanem Nowakiem, który sformułował ją następująco: „Postawą pewnego człowieka wobec pewnego przedmiotu jest ogół względnie trwałych dyspozycji do oceniania tego przedmiotu i emocjonalnego nań reagowania oraz 
sjach nad minioną rzeczywistością nadal dominuje subiektywny głos wielu uczestników ówczesnych zdarzeń, który - z powodu upływu czasu i nakładania się różnych, wtórnych narracji - jest głosem coraz bardziej odrealnionym ${ }^{3}$. Historykom brakuje także właściwego języka, użytecznego zarówno dla dokonania takiego opisu, jak i dla wyważonej oceny tych postaw. Konieczność poszukiwania narzędzi odmiennych od tradycyjnego warsztatu badacza minionych dziejów wynika ze specyfiki autorytarnego, momentami totalitarnego systemu, w którym jednostka zmuszona była do ukrywania własnych poglądów, a oficjalne życie społeczno-polityczne było przez większość tego okresu zrytualizowane i puste. Źródeł do badania tych czasów jest bardzo wiele, jednak przeważają wśród nich oficjalne, skażone wszechobecną cenzurą, dokonywaną także przez ich autorów ${ }^{4}$.

Co prawda problematyka postaw i zachowań społecznych jest przede wszystkim domeną socjologii, zachowania jednostek badane są także przez psychologów społecznych, jednak w czasach tzw. Polski Ludowej te dyscypliny naukowe również zostały zideologizowane, $\mathrm{w}$ związku z czym badania niezgodne z określonym przez władze „scenariuszem” nie mogły być prowadzone, a niewygodne dla niej wyniki nie wychodziły zazwyczaj poza mury uczelni ${ }^{5}$. Dlatego historycy, chcący odtworzyć postawy jednostek w ówczesnych warunkach społeczno-politycznych, nie mogą oprzeć się na wynikach tych badań i muszą poszukiwać takich danych i pojęć, które pomogą uzupełnić bądź zastąpić źródła niewiarygodne lub nieistniejące.

ewentualnie towarzyszących tym emocjonalno-oceniającym dyspozycjom względnie trwałych przekonań o naturze i własnościach tego przedmiotu i względnie trwałych dyspozycji do zachowania się wobec tego przedmiotu" (idem, Pojęcie postawy w teoriach $i$ stosowanych badaniach społecznych, [w:] Teorie postaw, red. S. Nowak, Warszawa 1973, s. 23).

3 O dyskusji historyków na temat postaw społeczeństwa polskiego wobec systemu komunistycznego zob.: T. Danilecki, Między zaangażowaniem, przystosowaniem i sprzeciwem. Postawy mieszkańców województwa białostockiego wobec wyborów powszechnych w latach 1957-1969, Białystok-Warszawa 2019, s. 19-25.

4 Jak podkreślał Marcin Kula, badanie postaw i myśli ludzi w systemie komunistycznym jest zadaniem trudnym, głównie z uwagi na brak porównywalnych („kompletnych, seryjnych i standaryzowanych") źródeł z tego samego czasu, co sprawia, że historyk, w odróżnieniu od socjologa, może jedynie „wskazać, jakie opinie funkcjonowały w społeczeństwie [...] opracować ich typologię, powiedzieć coś o ich zmienności - a nie określić precyzyjnie ich częstotliwość, rozkład geograficzny i społeczny. W tych kwestiach historyk zdany jest na intuicję, która jakże często jest z kolei odzwierciedleniem jego własnej opinii" (idem, Niemota ubezwłasnowolnionych, „Pamięć i Sprawiedliwość” 2000, nr 1, s. 72).

5 Dobrym przykładem są tutaj długofalowe badania postaw studentów Warszawy prowadzone przez zespół pod kierunkiem Stefana Nowaka w latach 1958, 1961 i 1978, które zostały opublikowane dopiero po upadku systemu (Studenci Warszawy. Studium dtugofalowych przemian postaw $i$ wartości, red. S. Nowak, Warszawa 1991). 
W niniejszym artykule, na przykładzie dróg życiowych trzech działaczy opozycyjnych, wywodzących się ze środowiska rolniczego Białostocczyzny: Jakuba Antoniuka, Kazimierza Bakuna i Jana Beszty-Borowskiego, zamierzam zbadać przydatność terminologii i definicji z zakresu filozofii i nauk społecznych do badań nad nonkonformistycznymi postawami i zachowaniami jednostek funkcjonujących $\mathrm{w}$ warunkach posttotalitarnego autorytaryzmu $^{6}$, z którym mieliśmy do czynienia w Polsce po 1956 r. aż do końca trwania systemu komunistycznego.

Do niniejszej analizy wybrane zostały losy osób, które - zarówno w rozumieniu potocznym, jak i w świetle dotychczasowych opisów dokonywanych przez historyków - można uznać za reprezentujące postawy „nonkonformistyczne". Ich drogi życiowe przebiegały niemal równolegle i w zbliżonych warunkach systemowych i społecznych. Należeli więc do tej samej kohorty demograficznej ${ }^{7} \mathrm{z}$ tym, że drogę życiową najstarszego z nich - Jakuba Antoniuka - odróżniało zarówno doświadczenie społecznej i politycznej, opozycyjnej aktywności w II Rzeczpospolitej, działalności konspiracyjnej podczas II wojny światowej, jak również represji okresu stalinowskiego. Wszystkie trzy osoby funkcjonowały $w$ warunkach prowincji, pochodziły ze wsi i miały wykształcenie podstawowe (chociaż Antoniuk był zdolnym samoukiem, a ponadto dokształcał się na różnych kursach). Ostatnim wreszcie argumentem za zestawieniem ze sobą tych właśnie życiorysów jest to, że zostały one już względnie dokładnie opisane, co umożliwia uproszczenie narracji $^{8}$. Podstawę źródłową niniejszego tekstu stanowić będą także osobiste

6 Mam tu na myśli głównie tę fazę rozwoju systemu komunistycznego w Polsce, która charakteryzowała się wybiórczym stosowaniem represji, ideologią ogarniającą jedynie zewnętrzne obszary życia jednostek i ograniczonym zakresem kontroli władzy nad społeczeństwem. Por.: L. Mażewski, Posttotalitarny autorytaryzm PRL 1956-1989. Analiza ustrojowopolityczna, Warszawa-Biała Podlaska, 2010, s. 9-13.

7 Za M. Mazurem przyjmuję, że kohorta demograficzna to „grupa osób w populacji, które $\mathrm{w}$ tym samym czasie doświadczyły ważnych $\mathrm{z}$ ich punktu widzenia wydarzeń - niekiedy traumatycznych - mających decydujący wpływ na całe ich dalsze życie (idem, Antykomunistycznego podziemia portret zbiorowy 1945-1956. Aspekty mentalno-psychologiczne, Warszawa-Lublin 2019, s. 32).

8 T. Danilecki, Beszta-Borowski Jan, [w:] Encyklopedia Solidarności. Opozycja w PRL 1976-1989, t. 1, red. M. Łątkowska, Warszawa 2010, s. 39-40; idem, Bakun Kazimierz, [w:] Encyklopedia Solidarności..., t. 2, red. G. Waligóra, Warszawa 2012, s. 24; idem, Między Marcem a Sierpniem. Przykłady postaw opozycyjnych mieszkańców Białostocczyzny w końcu lat sześćdziesiątych i w latach siedemdziesiatych XX w., "Studia Podlaskie" 2018, t. XXVI, s. 133-136; M. Kietliński, Jakub Antoniuk 1911-1988, [w:] Stownik biograficzny białostocko-łomżyński, Zeszyt 1, red. A. Dobroński et al., Białystok 2002, s. 11-12; idem, Jan Beszta-Borowski, [w:] Opozycja w PRL. Słownik biograficzny 1956-89, t. 1, red. J. Skórzyński et al., Warszawa 2000, s. 36-37; idem, 
wspomnienia Beszty-Borowskiego ${ }^{9}$ oraz informacje zawarte $\mathrm{w}$ materiałach operacyjnych Urzędu Bezpieczeństwa i Służby Bezpieczeństwa przechowywanych w Instytucie Pamięci Narodowej.

Opisanie historycznych konotacji pojęcia nonkonformizmu przekracza ramy niniejszego artykułu, warto jednak przypomnieć, że powstało ono w XVII-wiecznej Anglii i odnosiło się do przeciwników urzędowego Kościoła anglikańskiego ${ }^{10}$. W nauce jest ono rzadko definiowane, zwykle na marginesie dyskusji nad szeroko omawianym konformizmem, jako dewiacyjna odmiana tej postawy ${ }^{11}$. Potoczne rozumienie nonkonformizmu słownik języka polskiego definiuje jako „sprzeciw wobec bezkrytycznego ulegania normom panującym $\mathrm{w}$ danej grupie społecznej, niezgadzanie się z panującymi zwyczajami, poglądami, zasadami, z powszechną opinią itp."12. A więc pojęcie to ma z jednej strony wydźwięk raczej pozytywny, bowiem wyraża przemyślany, krytyczny stosunek jednostki wobec norm obowiązujących w danej grupie społecznej, z drugiej zaś kładzie nacisk na destrukcyjny wpływ zachowań nonkonformistycznych jednostki wobec porządku społecznego. Ten drugi element definicji zbliża rozumienie potoczne nonkonformizmu do podejścia antropologicznego, zgodnie z którym jednostki kwestionujące społeczny obyczaj i prawo społeczeństw pierwotnych były traktowane jak przestępcy. $\mathrm{Z}$ kolei negatywne $\mathrm{w}$ dzisiejszym, potocznym odbiorze pojęcie konformizmu, było dla społeczeństw pierwotnych przede wszystkim pozytywnym skutkiem procesu socjalizacji oraz - $\mathrm{w}$ znacznie mniejszym stopniu - mechanizmów kontroli społecznej (system formalnych i nieformalnych nagród i kar) realizowanej zarówno przez władzę, jak również pozostałych członków społeczności ${ }^{13}$.

Niezależny Samorządny Związek Zawodowy Rolników Indywidualnych "Solidarność” w województwie białostockim w latach 1980-1981, [w:] Mój Kościót w historię wpisany. Księga pamiątkowa dedykowana Księdzu Profesorowi Tadeuszowi Krahelowi, red. T. Kasabuła, A. Szot, Białystok 2007, s. 185-197; M. Kietliński, A. Szot, Z dziejów rolniczej „Solidarności” w województwie białostockim 1980-1989. Niezależny Samorządny Związek Zawodowy Rolników Indywidualnych "Solidarność" w świetle dokumentów archiwalnych, Białystok 2013, passim; J.J. Milewski, Jakub Antoniuk 1911-1988, [w:] Konspiracja i opór społeczny w Polsce 1944-1956. Stownik biograficzny, t. 1, Kraków-Warszawa-Wrocław 2002, s. 12-14; idem, Życie z kolcami, „Gazeta Współczesna" 10 X 1988; L. Postołowicz, Jakub Antoniuk 1911-1988, „Białostocczyzna” 1989, nr 1, s. $41-42$.

9 J. Beszta-Borowski, Pót wieku zarazy. Moje zapiski faktów i refleksji, Komorów [2002].

10 J. Paszkiewicz, O postawach konformizmu i nonkonformizmu, „Etyka” 1972, nr 10, s. 119.

11 Ibidem, s. 119-136.

12 Uniwersalny słownik języka polskiego PWN. K-Ó, red. S. Dubisz, Warszawa 2006, s. 1016.

13 E. Nowicka, Świat człowieka - świat kultury. Systematyczny wykład problemów antropologii kulturowej, Warszawa 1997, s. 416-419. 
Z kolei $\mathrm{w}$ socjologii - zgodnie $\mathrm{z}$ przyjmowaną przez wielu socjologów koncepcją Roberta K. Mertona - nonkonformizmu należy poszukiwać na skali pojęć składających się na zjawisko społecznego przystosowania (adaptacji). Autor ten wyróżnia pięć poziomów przystosowania: konformizm, innowację, rytualizm, wycofanie (rezygnację) i bunt. Umieszczony na początku tej skali konformizm opisuje jako akceptację zarówno norm społecznych, jak i wartości, zaś znajdujący się na jej przeciwnym końcu bunt - ich czynne odrzucenie. Innowacja oznacza akceptację wartości przy jednoczesnym odrzuceniu reguł i dążeniu do ich zmiany, rytualizm to bezrefleksyjne trwanie przy obowiązujących regułach, zaś rezygnacja to ich bierne odrzucenie. Poza konformizmem, pozostałe formy adaptacji są - zgodnie z tą koncepcją określane jako dewiacja społeczna ${ }^{14}$. W rozwiniętej wersji tej teorii bunt i rezygnacja są wyrazem nieprzystosowania. Odmianą konformizmu jest także legalizm, a więc postępowanie zgodne $z$ normą prawną i oportunizm, oznaczający przestrzeganie reguł pomimo ich nieuznawania ${ }^{15}$. Tak więc w ujęciu socjologicznym to, co potocznie nazywamy nonkonformizmem, będzie rodzajem innowacji lub buntu. Warto jednak zwrócić uwagę na przeciwstawność elementów obu tych pojęć. Bowiem o ile innowacja oznacza akceptację wartości społecznych, o tyle bunt jest ich kategorycznym odrzuceniem. Obie postawy łączy natomiast odrzucenie reguł postępowania obowiązujących $\mathrm{w}$ danym społeczeństwie ${ }^{16}$.

Definicje konformizmu formułowane w naukach społecznych starają się zdefiniować je jako zjawisko aksjologicznie neutralne i lokują je w polu oddziaływania grup społecznych ${ }^{17}$. Odwrotną perspektywę oglądu postawy konformizmu/nonkonformizmu przyjmuje się na gruncie filozofii. Dokonując namysłu nad tymi postawami współcześni filozofowie twierdzą, że nie da się wniknąć $w$ ich istotę tylko na podstawie oceny zachowań jednostki, bez analizy motywów jej działania, stąd wniosek, że „do badania konformizmu niewłaściwa jest perspektywa i metoda behawioryzmu"18. Postawę nonkonformistyczną charakteryzują oni jako postępowanie zgodne z własnym ,ja aksjologicznym" (tożsamością, sumieniem) ${ }^{19}$. Tak więc jest ona rozpatrywana bez odniesienia do zewnętrznego otoczenia. Podobne podejście prezento-

\footnotetext{
14 R. K. Merton, Teoria socjologiczna i struktura spoteczna, Warszawa 2002, s. 205-221.

P. Sztompka, Socjologia. Analiza społeczeństwa, Warszawa 2004, s. 283-284.

Szerzej zob. w części II pracy: T. Danilecki, Między zaangażowaniem...

7 J. Paszkiewicz, op. cit., s. 119-136.

18 A. Niemczuk, Konformizm contra nonkonformizm, [w:] Niezależni i ulegli. Studia o nonkonformizmie, red. R. E. Bernacka, Toruń 2008, s. 29.

19 Ibidem, s. 37-41.
} 
wane jest na gruncie socjologii prawa ${ }^{20}$. Z kolei wielu psychologów społecznych postrzega konformizm/nonkonformizm jako cechy osobowościowe, dzięki którym jednostka jest mniej lub bardziej skłonna do poddawania się opinii innych na dany temat ${ }^{21}$.

Badanie postaw konformizmu/nonkonformizmu jest szczególnie ciekawe w odniesieniu do warunków systemu komunistycznego, bowiem nonkonformizm nie mieścił się $\mathrm{w}$ jego ideologicznych ramach, a konformizm wynikał wprost z jego ideologicznych założeń. Przypomnijmy, że w centrum idealnego społeczeństwa komunistycznego miał być partyjny kolektyw, w którym jednostka stanowić miała tylko pozbawiony własnej woli element $^{22}$. Każde, nawet neutralne działanie jednostki wykraczające poza określony przez partię „scenariusz” zachowań mogło zostać zakwalifikowane jako skierowane przeciwko systemowi i skutkować koniecznością jej resocjalizacji lub anihilacji ${ }^{23}$.

$\mathrm{W}$ niedoskonałej praktyce komunizmu wykrystalizowały się z czasem trzy wzajemnie przenikające się grupy ludzi: biernie akceptujący system „konformiści”, walczący z nim „nonkonformiści”, a także zaangażowani w jego tworzenie "aktywiści" 24. Jak dowodzą socjologowie, w każdym społeczeństwie przeważają postawy przystosowania. Zaangażowanie i opór/sprzeciw znajdują się na przeciwnych krańcach tej krzywej i odzwierciedlają niewielki odsetek reprezentantów takich postaw/zachowań, podczas gdy postawy przystosowawcze znacznie przeważają nad pozostałymi ${ }^{25}$.

20 Maria Borucka-Arctowa pisze: „,[...] rozgraniczenie postępowania nonkonformistycznego od postępowania przestępczego nie jest możliwe bez sięgnięcia do motywów, które skłaniają jednostkę do określonego postępowania, a którymi w tym wypadku jest akceptacja takich bądź innych wartości oraz ich hierarchizacja. A zatem rozgraniczenie to jest możliwe jedynie na gruncie postaw społecznych" (eadem, Legalizm a konformizm i oportunizm, "Ruch Prawniczy, Ekonomiczny i Socjologiczny" 1964, nr 2, s. 243).

21 J. Paszkiewicz, op. cit., s. 127.

22 Y. Slezkine, Dom władzy. Opowieść o rosyjskiej rewolucji, t. 1: W drodze, przeł. G. Chodakowski-Gyurics et al., Warszawa 2019, s. 298-300.

23 H. Świda-Ziemba, Człowiek wewnętrznie zniewolony, Warszawa 1998, s. 111-114.

24 K. Kersten, Terror na przełomie wojny i pokoju, „Aneks” 1988, nr 51-52, s. 118-119.

Bazując na badanym przeze mnie $\mathrm{w}$ innym miejscu stosunku polskiego społeczeństwa do wyborów powszechnych w okresie gomułkowskiej „małej stabilizacji” mogę stwierdzić, że w skali kraju przypadków czynnego sprzeciwu, otwarcie wyrażanego np. poprzez ostentacyjną odmowę udziału w głosowaniu, publiczne niszczenie kart wyborczych czy otwarte wzywanie do bojkotu, było w całym tym okresie (poza specyficznymi wyborami do Sejmu w 1957 r. i późniejszymi o rok wyborami do rad narodowych) nie więcej niż tysiąc w skali kraju (T. Danilecki, Między zaangażowaniem..., s. 417-419). Potwierdza to chociażby także niewielka skala zaangażowania jednostek $\mathrm{w}$ działalność powojennej partyzantki niepodległościowej (M. Mazur, op. cit., s. 30-31). 
Poniższe życiorysy działaczy rolniczej, „solidarnościowej” opozycji obrazują trzy spośród szerokiego wachlarza różnych postaw oporu/sprzeciwu jednostek nonkonformistycznych funkcjonujących w warunkach systemu autorytarnego. Ich zestawienie obok siebie ma na celu pokazanie komplikacji przed którymi staje historyk, próbując dokonać oceny opisywanych przez siebie bohaterów wydarzeń.

Urodzony w 1911 r. Jakub Antoniuk był osobą nieprzeciętnie inteligentną, ambitną, aktywną i posiadającą zdolności przywódcze. Był też uzdolniony artystycznie. Pochodził z podbiałostockiej, drobnoszlacheckiej wsi Dobrzyniewo Duże. Jak możemy przeczytać w tajnej charakterystyce sporządzonej przez funkcjonariuszy SB w 1961 r., we wczesnej młodości sprawiał liczne kłopoty wychowawcze, wskutek których został usunięty ze szkoły ${ }^{26}$. Jako nastolatek zaangażował się w działalność społeczno-polityczną, wstępując do lokalnych struktur Centralnego Związku Młodzieży Wiejskiej, gdzie wykazał się talentem organizatorskim i szybko zaczął pełnić funkcje kierownicze na szczeblu gminy i powiatu. W 1932 r. zaczął organizować w regionie struktury konkurencyjnego Związku Młodzieży Wiejskiej RP „Wici”, działając jednocześnie w Zarządzie Wojewódzkim Stronnictwa Ludowego ${ }^{27}$. W 1937 r. uczestniczył w incydencie, w trakcie którego miał zranić nożem sąsiada, za co został skazany na rok więzienia. Jak pisał w latach osiemdziesiątych ubiegłego wieku Jan Jerzy Milewski, bójka była policyjną prowokacją, a Antoniuk "dzięki odpowiednim świadkom i składowi sędziowskiemu” stał się sprawcą, a nie ofiarą napadu. Do więzienia jednak nie trafił od razu z powodu składanych odwołań i apelacji ${ }^{28}$. Jeśli wierzyć informacjom z dokumentów „bezpieki” z początku lat pięćdziesiątych (opartym o zeznania aresztowanego po wojnie Adama Półtorzeckiego, kierownika Referatu Śledczego Komendy Powiatowej Policji Państwowej w Białymstoku), Antoniuk uniknął wówczas więzienia za cenę podjęcia tajnej współpracy z policją ${ }^{29}$. Jednak albo informacja ta była nieprawdziwa (Półtorzecki z pewnością nie składał zeznań przed funkcjonariuszami UB dobrowolnie, a „bezpieka” szukała wówczas informacji, mogących obciążyć Antoniuka, o czym niżej), albo (co w świetle późniejszych faktów z jego życia wydaje się bardziej prawdopodobne) do faktycznej współpracy z policją nie doszło, lub też nie była ona

26 Archiwum Instytutu Pamięci Narodowej w Warszawie (dalej: AIPN Wa), sygn. 01236/20, Charakterystyka figuranta sprawy operacyjnej obserwacji nr 346/186037, k. 100.

28 Idem, Życie z kolcami...

29 AIPN Wa, sygn. 01236/20, Charakterystyka figuranta sprawy operacyjnej obserwacji nr 346/186037, k. 100. 
satysfakcjonująca. W każdym razie tuż po wyroku Antoniuk zaczął w ostry sposób, publicznie krytykować władze sanacyjne i ruch narodowy. Jedno $\mathrm{z}$ tego typu przemówień, wygłoszone $\mathrm{w}$ Białymstoku podczas demonstracji 1 maja $1938 \mathrm{r}$. odnotowano w lokalnej prasie. Swoje antysanacyjne artykuły publikował także w prasie ludowej i w „Robotniku Białostockim”, podpisując je pełnym imieniem i nazwiskiem. Zapewne dlatego 8 października 1938 r., w drodze na kongres SL do Warszawy zatrzymano go i osadzono w Miejscu Odosobnienia w Berezie Kartuskiej, gdzie pozostał aż do wybuchu wojny ${ }^{30}$. Należy tu podkreślić, że zarówno moment zatrzymania, jak i jego podstawa (decyzja administracyjna, a nie wyrok sądu), a także miejsce uwięzienia, zdają się potwierdzać polityczny, a nie kryminalny charakter sprawy ${ }^{31}$.

Nie wiemy nic o jego aktywności w okresie okupacji sowieckiej lat 1939-1941. Można tylko przypuszczać, że fakt uwięzienia w Berezie Kartuskiej mógł mu zapewnić względny spokój. W latach okupacji niemieckiej Antoniuk zaangażował się w budowę okręgowych struktur Batalionów Chłopskich, chociaż nawet życzliwi mu historycy powątpiewali w jego powojenne relacje, jakoby miał pełnić funkcję komendanta okręgu białostockiego $\mathrm{BCh}^{32}$. Od 1943 r. włączył się w działalność Armii Krajowej pod pseudonimem „Walgierz" ${ }^{\prime 3}$. Także powojenny życiorys Antoniuka jest pełen sprzeczności i działań - z pozoru przynajmniej - wykluczających się.

W 1944 r., z rekomendacji SL objął kilka funkcji publicznych. Został m.in. wicewojewodą białostockim ${ }^{34}$. Jednocześnie przesyłał lokalnym strukturom AK meldunki wywiadowcze, za co w lutym 1945 r. został skazany na karę śmierci. Jednak na skutek interwencji Naczelnego Komitetu Wykonawczego SL uwolniono go tuż przed wyborami do Sejmu w 1947 r. ${ }^{35}$ Ponownie rozpoczął działalność $\mathrm{w}$ ruchu ludowym i zaangażował się oficjalnie w tworzenie Związku Młodzieży Polskiej, jednak prywatnie miał zniechęcać do wstępowania do tej organizacji. W następnym roku został usunięty z SL i ZMP za „rozbijacką robotę” i „ułatwianie otrzymania zapomóg człon-

30 J.J. Milewski, Życie z kolcami...

31 Faktem jest, że od października 1937 r. do Miejsca Odosobnienia w Berezie Kartuskiej kierowano także kryminalistów i sprawców nadużyć gospodarczych, którzy w 1938 r. stanowili już połowę osadzonych (W. Śleszyński, Obóz odosobnienia w Berezie Kartuskiej 1934-1939, Białystok 2003, s. 85-86).

32 J.J. Milewski, Życie z kolcami...; L. Postołowicz, op. cit., s. 41.

33 J.J. Milewski, Jakub Antoniuk..., s. 12. Zob. też: Partyzanckie ścieżki, red. H. Matejczyk, Białystok 1957.

34 T. Danilecki, Między Marcem..., s. 133, przyp. 101.

35 Ibidem. 
kom band" 36 . Wkrótce ponownie zainteresował się nim aparat bezpieczeństwa, wskutek czego został zarejestrowany przez WUBP w Białymstoku jako tajny współpracownik ${ }^{37}$. Wprawdzie szczegóły jego współpracy nie są znane, ponieważ materiały, które ją dokumentowały zniszczono ${ }^{38}$, jednak początkowo musiała ona być oceniana przez UB bardzo wysoko, skoro w $1954 \mathrm{r}$. planowano przerzucenie Antoniuka na Zachód, gdzie miał zająć się rozpracowaniem emigracyjnych struktur ruchu ludowego. Jednak przeprowadzona w związku z tymi planami szczegółowa analiza jego meldunków doprowadziła funkcjonariuszy kontrwywiadu MBP do wniosku, że jest on „wrogo ustosunkowany do PRL, którą uważa za 17-ą republikę, nienawidzi ZSRR i oczekuje na wybuch III-ciej wojny i zmianę ustroju w Polsce" ${ }^{39}$. W 1956 r. funkcjonariusze UB doszli do wniosku, że większość informacji, których udzielił, była nieprawdziwa i skreślili go z sieci agenturalnej ${ }^{40}$. Jesienią tego roku Antoniuk zaczął publicznie domagać się rehabilitacji lokalnych działaczy SL represjonowanych po 1948 r., zerwania przez Stronnictwo współpracy z Polską Zjednoczoną Partią Robotniczą i zmiany kierownictwa w lokalnych strukturach obu ugrupowań ${ }^{41}$. W 1961 r. został wykluczony z ZSL za "działalność prawicową" 42 .

W 1977 r. SB zaczęła po raz kolejny rozpracowywać Antoniuka w związku z - jak to określono - działalnością skierowaną „przeciwko linii politycznej” PZPR. Sprawie nadano symbolicznie brzmiący kryptonim „Zago-

36 J.J. Milewski, Jakub Antoniuk..., s. 13.

37 T. Danilecki, Między Marcem..., s. 133, przyp. 101.

38 Jego nazwiskiem podpisane jest (podpis jest maszynowy, a nie odręczny), pochodzące prawdopodobnie z 1950 r., czterostronicowe „Sprawozdanie z działalności Chłostry (Chłopskiej Straży), BCh (Bataliony Chłopskie) oraz Stronnictwa Ludowego (ROCH) na terenie województwa białostockiego podczas okupacji niemieckiej". Zob.: Oddziałowe Archiwum Instytutu Pamięci Narodowej w Białymstoku (dalej: AIPN Bi), sygn. 011/9, Sprawa operacyjnego rozpracowania byłych członków Chłopskiej Straży (Chłostra), Batalionów Chłopskich oraz Stronnictwa Ludowego, działających podczas okupacji niemieckiej na terenie woj. białostockiego (1943-1953), k. 12-15).

39 AIPN Wa, sygn. 01236/20, Raport st. ref. Samodzielnej Grupy Departamentu I ppor. W. Tomczyka z podróży służbowej do WUBP w Białymstoku, [1955], k. 95.

40 T. Danilecki, Między Marcem..., s. 133, przyp. 101.

41 Idem, Między zaangażowaniem..., s. 60. Według raportów SB, Antoniuk miał też zorganizować wokół siebie grupę członków będących w opozycji do władz wojewódzkich Stronnictwa, jednak jego próby wejścia w skład Wojewódzkiego Komitetu ZSL nie powiodły się. Znalazł się natomiast w sekretariacie regionalnego Tymczasowego Komitetu Organizacyjnego ZMW (M. Markiewicz, Odwilż na prowincji. Białostocczyzna 1956-1960, Białystok-Warszawa 2019, s. 210, 254).

42 AIPN Wa, sygn. 01236/20, Charakterystyka figuranta sprawy operacyjnej obserwacji nr 346/1860/37, 18 X 1961, k. 53. 
rzały" ${ }^{43}$. Dalsza aktywność polityczna Antoniuka przerodziła się wkrótce w działalność stricte opozycyjną wobec systemu. W czerwcu 1979 r. zaangażował się w działalność nielegalnego Ośrodka Myśli Ludowej ${ }^{44}$. Jednak prowadził równocześnie rozmowy z funkcjonariuszami SB. Mówił im bardzo dużo, ale przekazywał takie informacje i godził się na realizację takich zadań, których nie mogli oni zweryfikować. Na początku 1980 r. "esbecy” zorientowali się, że Antoniuk próbuje ich oszukiwać ${ }^{45}$. Wkrótce kontakty z nim zaczęli traktować głównie jako sposób na ograniczenie jego nielegalnych działań na terenie lokalnym i starali się skierować ją na grunt OML ${ }^{46}$. Działania Antoniuka polegały na gromadzeniu nielegalnej literatury, formułowaniu i podpisywaniu otwartych listów i petycji do władz i udziale w spotkaniach nielegalnych gremiów, na które jeździł do Warszawy i organizował we własnym domu ${ }^{47}$.

Po podpisaniu Porozumień Sierpniowych Antoniuk zaangażował się w tworzenie Niezależnego Związku Zawodowego Rolników „Solidarność Wiejska" i został wiceprzewodniczącym jego ogólnopolskich struktur oraz przewodniczącym Wojewódzkiego Komitetu Organizacyjnego ${ }^{48}$. Równocześnie poinformował o swoich działaniach SB. W meldunku opisującym tę rozmowę funkcjonariusz SB ppłk Anatol Antończyk napisał: „Figurant, pomimo systematycznie prowadzonych rozmów przez nas, jest dwulicowym, stąd też należy jego informacje konfrontować z innymi ustaleniami" 49 .

Wiosną 1981 r. Antoniuk wszedł w konflikt o przywództwo w regionalnych strukturach opozycyjnego ruchu ludowego z Janem Besztą-Borowskim ${ }^{50}$, wskutek czego na miesiąc przed wprowadzeniem stanu wojennego rozpoczął, wraz z Kazimierzem Bakunem, tworzenie konkurencyjnych struk-

43 Materiały tej sprawy zostały zniszczone. Zob.: AIPN Bi, Wypis kartoteczny OBUiAD w Białymstoku dot. J. Antoniuka, 10 I 2008.

44 M. Choma-Jusińska, Ośrodek Myśli Ludowej, http://www.encysol.pl/wiki/Ośrodek_Myśli_ Ludowej [dostęp: 9 VI 2020].

45 AIPN Bi, sygn. 012/302, Meldunek operacyjny z 13 II 1980, k. 48v.

46 Ibidem, Meldunek operacyjny z 25 III 1980, k. 55; ibidem, Meldunek operacyjny z 7 VI 1980, k. $61 \mathrm{v}$.

47 T. Danilecki, Między Marcem..., s. 133-134.

48 M. Kietliński, Niezależny Samorządny..., s. 186.

49 AIPN Bi, sygn. 012/302, Meldunek operacyjny z 30 IX 1980, k. 70.

50 Podczas zjazdu założycielskiego regionalnych struktur NSZZ „S" Rolników Indywidualnych, który odbył się 3 maja 1981 r. w Łapach, został wybrany jedynie honorowym przewodniczącym Prezydium Wojewódzkiego Komitetu tej organizacji (J.J. Milewski, Jakub Antoniuk..., s. 13. Szerzej na ten temat zob.: J. Beszta Borowski, Pół wieku zarazy..., passim; M. Kietliński, Niezależny Samorzadny..., s. 186-190). 
tur NSZZ Rolników „Solidarność Wiejska”51. Po wprowadzeniu stanu wojennego, w odróżnieniu od wielu innych działaczy NSZZ „Solidarność” Rolników Indywidualnych, nie prowadził działalności opozycyjnej i nie był represjonowany. Natomiast tuż po powtórnym internowaniu Beszty-Borowskiego, które nastąpiło 10 września 1982 r., napisał do komendanta wojewódzkiego $\mathrm{MO}$ w Białymstoku list, w którym domagał się umorzenia dochodzenia przeciwko swemu niedawnemu konkurentowi i uchylenia decyzji o jego internowaniu dowodząc, że Beszta-Borowski jest ,,jednostką niedorosłą do miana rzeczywistego działacza ludowego" 52 .

O późniejszej działalności opozycyjnej Antoniuka nic nie wiadomo. W rejestrach SB z końca lat osiemdziesiątych występował jako TW „Radziszewski" 53, jednak nie ma żadnych materialnych dowodów jego ewentualnej współpracy z SB. Zmarł 10 lipca 1988 r. Lokalny historyk Leszek Postołowicz podsumował wówczas jego życiorys następująco: „[...] miał predyspozycje, aby w politycznej karierze zajść wysoko, pod jednym wszakże warunkiem - musiał przyjąć reguły gry politycznej, aby móc łagodnie wchodzić w zakręty i nie wypadać na wirażach" ${ }^{54}$. Z kolei Jan Jerzy Milewski zauważał: „Nie potrafił jednak skupić wokół siebie jakiejś poważniejszej grupy ludzi, a z większością swych współtowarzyszy z ruchu młodzieżowego i ludowego pozostał skłócony do końca życia" 55 . Nie był również lubiany w środowisku sąsiedzkim, gdzie uważano go za typowego pieniacza. Koledzy z czasów wojennej konspiracji zarzucali mu polityczny koniunkturalizm ${ }^{56}$.

Przykładem odmiennej postawy jest droga życiowa wspomnianego już Kazimierza Bakuna, właściciela gospodarstwa rolnego we wsi Starowlany w gminie Kuźnica Białostocka, pracującego równocześnie na kolei ${ }^{57}$. Skromna podstawa źródłowa, jaką stanowią akta operacyjne i sądowe przechowywane w IPN, nie pozwala na pełne odtworzenie źródeł jego nonkonformistycznej postawy życiowej. Jak wynika z tych akt, cechował go zdecydowany antykomunizm - postawa dość powszechna wśród większości katolickich mieszkańców tej przygranicznej gminy, żywo pamiętających represje okresu „pierwszego Sowieta”, spośród których wielu zostało dotkliwie po-

51 T. Danilecki, Bakun Kazimierz..., s. 24.

52 AIPN Bi, sygn. 625/25, List Jakuba Antoniuka do komendanta wojewódzkiego MO w Białymstoku, 15 X 1982, [brak paginacji stron].

53 AIPN Bi, Wypis ewidencyjny BUiAD w Warszawie dot. J. Antoniuka, 8 V 2008.

54 J.J. Milewski, Życie z kolcami...

55 L. Postołowicz, op. cit., s. 41.

56 P. Borowski, Czy tylko genialny samouk?, "Gazeta Współczesna” 7 XI 1988.

57 T. Danilecki, Między Marcem..., s. 135. 
szkodowanych $\mathrm{w}$ wyniku wytyczenia po wojnie polsko-sowieckiej granicy w poprzek gospodarstw, naturalnych więzi rodzinnych i kulturowych ${ }^{58}$. Postawy antykomunistyczne tej społeczności utrwaliły także z pewnością represje związane z przymusową kolektywizacją ${ }^{59}$.

Według rozmowy, którą Kazimierz Bakun miał odbyć 23 kwietnia 1980 r. z funkcjonariuszem SB, o jego zaangażowaniu się w działalność opozycyjną przesądziło poczucie krzywdy, jakiej doznał w połowie lat siedemdziesiątych ze strony Centrali Nasiennej w Sokółce, która - mimo korzystnych dla niego wyroków sądów - odmówiła zwrotu nadpłaconych przezeń pieniędzy za zakupione ziemniaki ${ }^{60}$. To skłoniło go do napisania skargi do Komitetu Praw Człowieka w Genewie i złożenia wniosku do Przewodniczącego Rady Państwa w sprawie zrzeczenia się obywatelstwa polskiego. Podjął wówczas także kontakty z Wiesławem Kęcikiem, działaczem Komitetu Obrony Robotników zajmującym się sprawami rolnictwa. Jako współpracownik KOR, zorganizował na terenie województwa białostockiego sieć kolportażu pism bezdebitowych, co szybko wzbudziło zainteresowanie ze strony $\mathrm{SB}^{61}$. Jednak mimo gróźb funkcjonariuszy, stosowanych naprzemiennie z obietnicami rozwiązania problemów finansowych, Bakun nie przerwał kolportażu i publicznie krytykował porządki panujące na wsi. Warto dodać, że w jego opozycyjnej działalności wspierała go czynnie żona.

Jesienią 1980 r., wraz z Jakubem Antoniukiem i Janem Besztą-Borowskim, zaangażował się w tworzenie NZZR "Solidarność Wiejska” i został wiceprzewodniczącym Wojewódzkiego Komitetu Organizacyjnego związku, a w maju 1981 r. - wiceprzewodniczącym Wojewódzkiego Komitetu Założycielskiego NSZZ "S" RI. Wiosną tego roku uczestniczył też w strajku chłopskim w Rzeszowie ${ }^{62}$. Z powodu swoich działań w 1980 r. Bakun stawał pięciokrotnie przed kolegium, które wymierzało mu za każdym razem kary grzywny, aresztu lub ograniczenia wolności. Wskutek ciągłych szykan ze strony przełożonych zwolnił się z pracy ${ }^{63}$. W $1981 \mathrm{r}$. przez wiele tygodni przyjeżdżał codziennie do Białegostoku i osobiście przyjmował setki intere-

58 Zob.: K. Sokół, Granica polsko-radziecka w latach 1944-1948 w okolicach Kuźnicy. Doświadczenia mieszkańców, mps pracy magisterskiej obronionej na Uniwersytecie w Białymstoku, 2006, passim.

59 Zob.: M. Markiewicz, Kolektywizacja wsi w województwie białostockim 1948-1956, Białystok 2010, s. 200-236.

60 AIPN Bi, sygn. 012/320, Meldunek operacyjny z 28 IV 1980, k. 31v.

61 T. Danilecki, Między Marcem..., s. 135.

62 Idem, Bakun Kazimierz..., s. 24.

63 Idem, Między Marcem..., s. 136. 
santów. Po tym, jak przewodniczący MKZ NSZZ „Solidarność” Regionu Białystok Feliks Gołębiewski wymówił rolniczej "S" siedzibę w budynku przy ul. Nowotki, Bakun przyjmował interesantów na korytarzu i na schodach ${ }^{64}$. Od jesieni 1981 r., wraz z Antoniukiem zaangażował się w odtwarzanie konkurencyjnych wobec NSZZ „S" RI struktur „Solidarności Wiejskiej” 65.

Po wprowadzeniu stanu wojennego Bakun został na niespełna miesiąc aresztowany pod pretekstem niezapłacenia grzywny. Tuż po zwolnieniu zatrzymano go ponownie, tym razem pod zarzutem znieważenia funkcjonariuszy MO, zaś w marcu 1982 r. trafił do aresztu na trzy miesiące i został ukarany grzywną za namawianie po 13 grudnia 1981 r. rolników do bojkotu państwowego skupu produktów. W kwietniu 1982 r. skazano go na rok pozbawienia wolności za wspomniane już znieważenie milicjantów. $Z$ więzienia został zwolniony przedterminowo, ponieważ nękany wyrokami i grzywnami, zgodził się wyemigrować z Polski wraz z żoną i pięciorgiem dzieci, co też uczynił w końcu 1982 r. Zmarł w 1998 r. na emigracji66.

Ostatnim przykładem strategii nonkonformistycznej w kontaktach z władzą autorytarną jest życiorys urodzonego w 1936 r. Jana Beszty-Borowskiego. Pochodził on z rodziny drobnoszlacheckiej od wieków osiadłej w okolicach Turośni Kościelnej. Charakterystycznym zdarzeniem z dzieciństwa, zapamiętanym przez niego jako istotne dla późniejszej postawy życiowej, była bezkompromisowa obrona ideałów zaprezentowana przez jego matkę w rozmowie z sowieckim żołnierzem, który pojawił się latem 1944 r. w ich rodzinnym domu. Grożąc bronią przekonywał kobietę, że Polska będzie po wojnie sowiecką republiką i przestanie istnieć jako niezależne państwo. Matka nie przestraszyła się i uparcie, głośno powtarzała: „Polska musi być, i to wolna”. Jan Beszta-Borowski zapisał po latach: „W tej krótkiej chwili, którą zapamiętałem na całe życie, przeżyłem strach i podziw - oto matka naraża życie za Polskę, nie za jakieś tam buty czy kożuchy, ale za coś jeszcze wtedy dla mnie nieuchwytnego - Polskę" 67. Kolejne zdarzenie, które nastąpiło w 1946 r., było pierwszym testem jego osobistej odwagi. Napisał wówczas szkolne wypracowanie na temat: „Co nam dała przyjaźń polsko-radziecka?”. Jak wspominał po latach: „Wielu pisało tak, jak gazety, i jak oczekiwał inspektor. Rodził się konformizm również u dzieci, wyczuwały one, jakiego poglądu oczekuje od nich władza. Ja pisałem tak, jak myślałem". Skutkiem takiej treści

\footnotetext{
64 J. Beszta-Borowski, op. cit., s. 46.

65 T. Danilecki, Bakun Kazimierz..., s. 24.

66 Ibidem.

67 J. Beszta-Borowski, op. cit., s. 9-10.
} 
wypracowania było wezwanie ojca na przesłuchanie ${ }^{68}$. W 1951 r., jak wielu młodych ludzi w tym okresie, Beszta-Borowski, wówczas uczeń Państwowego Technikum Mechaniki Rolnej w Białymstoku, zaangażował się w utworzenie nielegalnej organizacji młodzieżowej „Białe Orły”. Po dwóch latach działalności - wskutek donosu - został aresztowany i skazany na dwa i pół roku więzienia. Część zmniejszonego później wyroku przepracował w kopalni. Następnie, mimo utrudnień ze strony UB, zdołał dokończyć przerwaną naukę. Niedługo potem, w zastępstwie służby wojskowej, rozpoczął pracę jako górnik w KWK „Miechowice”. Jak pisał w swych wspomnieniach: „[...] od wyjścia z więzienia postanowiłem, że na moim ciele mundur ich wojska nigdy leżał nie będzie, choćbym miał iść do więzienia po raz drugi" ${ }^{\prime}$. W 1960 r., tuż po zakończeniu zastępczej pracy w kopalni, został skazany na karę ośmiu miesięcy pozbawienia wolności za rzekome niewywiązywanie się z dostaw obowiązkowych. Rzeczywistym powodem skazania był czynny opór, jaki stawiał komornikowi i funkcjonariuszom milicji, ponieważ chcieli oni zabrać mu trzodę za podatek, którego - jak twierdzili wbrew faktom nie zapłaci7 ${ }^{70}$.

Przez kolejnych niemal dwadzieścia lat Beszta-Borowski pracował głównie w państwowych ośrodkach maszynowych i tzw. kółkach rolniczych. Przez cały ten czas - jak wspominał - otwarcie występował przeciwko lokalnym klikom, korupcji i kradzieżom mienia państwowego, narażając się na ostracyzm ze strony otoczenia. W 1979 r., z powodu złego stanu zdrowia przeszedł na rentę

Momentem przełomowym na jego drodze do działalności opozycyjnej była pierwsza pielgrzymka Jana Pawła II do Polski, którą głęboko przeżył ${ }^{72}$. Wkrótce mocno zaangażował się $\mathrm{w}$ działalność antysystemową: dostarczał prowiant i pieniądze stoczniowcom strajkującym w sierpniu $1980 \mathrm{r}$. w Gdańsku, założył w swoim domu punkt informacyjny dla zainteresowanych tworzeniem niezależnych rolniczych struktur związkowych, w styczniu 1981 r. uczestniczył w strajkach chłopskich w Ustrzykach Dolnych i w Rzeszowie, w marcu został wybrany w skład Ogólnopolskiego Komitetu Założycielskiego NSZZ „Solidarność” Rolników Indywidualnych. W maju został powołany na przewodniczącego Wojewódzkiego Komitetu Założyciel-

\footnotetext{
68 Ibidem, s. 11.

69 Ibidem, s. 23.

70 Ibidem, s. 25.

71 T. Danilecki, Beszta-Borowski..., s. 40.

72 J. Beszta-Borowski, op. cit., s. 35.
} 
skiego związku, pokonując głównego konkurenta - Jakuba Antoniuka ${ }^{73}$. Wcześniej wszedł w konflikt z Feliksem Gołębiewskim, przewodniczącym MKZ NSZZ „S" Regionu Białystok ujawniając niewygodne dla niego fakty z młodości, co stało się jednym z powodów złożenia przez Gołębiewskiego dymisji ${ }^{74}$.

Przez kolejne miesiące „karnawału Solidarności” Jan Beszta-Borowski organizował struktury związku $\mathrm{w}$ terenie, pomagał $\mathrm{w}$ rozwiązywaniu problemów setkom zgłaszających się chłopów, uczestniczył w rozwiązywaniu lokalnych konfliktów między mieszkańcami wsi a władzami lokalnymi. Po wprowadzeniu stanu wojennego znalazł się w gronie 58 osób internowanych z województwa białostockiego. Podczas pierwszego przesłuchania w KW MO odmówił podpisania oświadczenia o przyjęciu do wiadomości dekretu o stanie wojennym, kilka dni później nie podpisał także „lojalki”, od czego funkcjonariusze SB uzależniali zwolnienie $\mathrm{z}$ internowania. Pomimo to postanowiono go zwolnić ze względu na zły stan zdrowia. Miał opuścić areszt w wigilię Bożego Narodzenia, jednak odmówił wyjścia do momentu zwrotu grawerowanego ryngrafu z orłem w koronie i Matką Boską, skonfiskowanego przez milicjantów podczas zatrzymania ${ }^{75}$.

Na wolności ponownie zaangażował się $\mathrm{w}$ działalność podziemną, będąc animatorem i wykonawcą większości, niejednokrotnie spektakularnych, akcji ulotkowych i plakatowych w okolicach Łap, organizując realną pomoc represjonowanym kolegom i ich rodzinom, a także druk i kolportaż podziemnej prasy. We wrześniu 1982 r. został ponownie internowany na ponad dwa miesiące. Po zwolnieniu kontynuował nielegalną działalność i był jeszcze kilkakrotnie zatrzymywany i aresztowany. W wyborach do Sejmu z czerwca 1989 r. został wybrany posłem z ramienia Komitetu Obywatelskiego. Nadal jednak prezentował radykalną postawę antykomunistyczną: w proteście przeciwko poparciu kandydatury gen. Wojciecha Jaruzelskiego na urząd prezydenta RP przez część posłów Obywatelskiego Klubu Parlamentarnego zawiesił swoje członkostwo w tym Klubie. W Sejmie przedstawił projekty uchwał: „O bezprawności stanu wojennego" i „O uznanie UB, IW, SB za organizacje przestępcze i zbrodnicze, splamione krwią męczeńską Narodu Polskiego". Wystąpił też o rehabilitację rtm. Witolda Pileckiego. W 2002 r.

73 T. Danilecki, Beszta-Borowski..., s. 39.

74 Idem, Działania Stużby Bezpieczeństwa wobec NSZZ „Solidarność" Regionu Białystok w latach 1980-1981, [w:] Początki „Solidarności” w pótnocno-wschodniej Polsce (1980-1981), Białystok 2005, s. 51-52. Por.: J. Beszta-Borowski, op. cit., s. 47, 52.

75 J. Beszta-Borowski, op. cit., s. 72-74. 
odmówił przyjęcia Złotego Krzyża Zasługi przyznanego przez ówczesnego prezydenta Aleksandra Kwaśniewskiego. Organizował także i przewodniczył regionalnym strukturom Ruchu Odbudowy Polski ${ }^{76}$.

Przedstawione powyżej życiorysy obrazują różne strategie funkcjonowania jednostek nonkonformistycznych $\mathrm{w}$ systemie autorytarnym. O Jakubie Antoniuku można by - dokonując powierzchownej oceny - powiedzieć, że był koniunkturalistą, który w działalności opozycyjnej znajdował ujście dla swoich osobistych ambicji. Jednak jego koniunkturalizm miał swoje podstawy w psychologicznie uwarunkowanych, woluntarystycznych cechach charakteru, a antysystemowa postawa wynikała z bogatej, wyrastającej ponad przeciętność osobowości, nie znoszącej ograniczeń. Dramatyczne wydarzenia z młodości, kiedy jako niedoświadczony działacz polityczny został poddany szantażowi ze strony funkcjonariuszy sanacyjnego aparatu policyjnego, niewątpliwie wpłynęły na przyjmowane przezeń później strategie kontaktów z władzą. Ktoś o tak silnych cechach woluntarystycznych, działając w warunkach systemu komunistycznego, z pewnością nie mógłby jak czyniło to wielu - realizować się $\mathrm{w}$ partii komunistycznej $\mathrm{z}$ uwagi na kolektywistyczne podstawy jej ideologii. Tymczasem wyszukiwanie jednostek mających wpływ na szersze otoczenie i wykorzystywanie ich skłonności do koniunkturalizmu było jednym z systemowych mechanizmów, mających na celu utrzymanie kontroli władzy nad społeczeństwem ${ }^{77}$. Tacy ludzie jak Antoniuk, stając przed groźbą utraty życia, wchodzili w nieoficjalne kontakty z systemem, wskutek czego musieli później samotnie mierzyć się z rozbudowanym aparatem kontroli i przemocy państwa. Andrzej Niemczuk, dokonując fenomenologicznej i aksjologicznej analizy zjawiska konformizmu pisał, że zdolność wykorzystywania przez jednostkę koniunktury jest umiejętnością pozytywną do czasu, gdy koniunktura jest „traktowana instrumentalnie". Aksjologicznie negatywna staje się wówczas, gdy człowiek się w niej „zatraca”, gdy „,́rodek zaczyna być ważniejszy od celu”.

Koniunkturalizm zatem - pisze autor - jako praktyczna umiejętność wykorzystania dla własnych celów obiektywnej koniunktury, zawiera w sobie zjawisko „panowania nad sytuacją" i autonomię podmiotu, który nie podlega temu, w czym uczestniczy, lecz tylko - by tak rzec - eksploatuje dla własnych celów zachodzące w świecie procesy obiektywne. Jednak gdy „eksploatowanym” zaczyna być sam podmiot, wówczas koniunkturalizm przechodzi w [...] jedną z postaci konformizmu ${ }^{78}$.

\footnotetext{
76 T. Danilecki, Beszta-Borowski..., s. 40.

77 H. Świda-Ziemba, op. cit., s. 237-258.

78 A. Niemczuk, op. cit., s. 28.
} 
Przypadek Jakuba Antoniuka jest dobrym przykładem tego, że w kontaktach z wszechwładnym aparatem państwa komunistycznego, koniunkturalizm był strategią obrony „własnego ja” skazaną na niepowodzenie, kończącą się porażką jednostki.

O drugim z bohaterów niniejszego artykułu Kazimierzu Bakunie można by powiedzieć, że podejmując decyzję o wejściu w spór z systemem, kierował się poczuciem doznanej odeń krzywdy, natomiast decydując się na emigrację, ulegał systemowi i porzucał postawę nonkonformistyczną na rzecz osiągnięcia poprawy komfortu życia materialnego i psychicznego własnego i rodziny. Jednak biorąc pod uwagę jego dojrzały już wiek, brak wykształcenia i znajomości języków obcych, a także pięcioro dzieci na utrzymaniu, należałoby stwierdzić, że jego emigracja była raczej dramatycznym wyrazem buntu, kategoryczną odmową wszelkich dalszych kontaktów z systemem, symbolicznym zerwaniem z nim i odmową pójścia na jakikolwiek kompromis. Był jak niewolnik z tekstu Alberta Camusa, „któremu rozkazywano przez całe życie [i który] stwierdza nagle, że nowy rozkaz jest nie do przyjęcia. [...] W pewien sposób przeciwstawia uciskającemu go porządkowi prawo do niepodlegania mu, jeśli przekroczył granicę, na którą może przystać"79. Jego bunt okazał się ostatecznie strategią zerwania, ucieczki.

Podobną podstawę buntu - za niesprawiedliwość doznaną ze strony przedstawicieli aparatu komunistycznego państwa - można dostrzec w życiorysie Jana Beszty-Borowskiego. Innymi komponentami wzmacniającymi jego postawę życiową były: wyniesiony z domu rodzinnego patriotyzm i charakterologiczna bezkompromisowość w prezentowaniu swojego sprzeciwu. Przyjęta od początku niezgoda na wszelkie kompromisy, a nawet jakikolwiek dialog z systemem zdecydowanie odróżniała go od Antoniuka. Z kolei z Bakunem różniła go reakcja na prześladowania. Być może $w$ tym względzie o zachowaniu Bakuna przesądzała konieczność opieki nad liczną rodziną? Tego się już zapewne nie uda rozstrzygnąć.

Wszystkie opisane powyżej osoby prowadziły aktywną działalność na rzecz wyższych wartości, jednak każda z nich przyjęła inną strategię radzenia sobie z zewnętrzną opresją. $Z$ pewnością nie bez wpływu na dokonywane przez nie wybory pozostawała ich konstrukcja charakterologiczna. Jej określenie nie jest jednak możliwe bez analizy psychologicznej. Już chociażby ten element dowodzi, że powyższe opisy są niepełne (i w przypadku postaci historycznych pełne być nie mogą). Jednak sądzę, że historyk dokonujący tylko suchego opisu faktów, bez prób wnikania w motywacje opisywanych

79 A. Camus, Człowiek zbuntowany, przeł. J. Guze, Warszawa 2002, s. 21-22. 
bohaterów zdarzeń i głębsze konteksty ich życiorysów, byłby może w stanie odpowiedzieć na pytanie o to, jak i kiedy dane wydarzenie przebiegało i kto w nim uczestniczył. Nie umiałby jednak odpowiedzieć na najciekawsze pytanie: dlaczego?

\section{Bibliografia}

\section{Źródła archiwalne}

Archiwum Instytutu Pamięci Narodowej w Warszawie:

- sygn. 01236/20.

Oddziałowe Archiwum Instytutu Pamięci Narodowej w Białymstoku:

- sygn. 011/9

- sygn. 012/302

- sygn. 012/320

- sygn. $625 / 25$

- wypisy ewidencyjne i kartoteczne BUiAD w Warszawie dot. J. Antoniuka.

\section{Wspomnienia i relacje}

Beszta-Borowski J., Pót wieku zarazy. Moje zapiski faktów i refleksji, Komorów [2002].

\section{Materiały niepublikowane}

Sokół K., Granica polsko-radziecka w latach 1944-1948 w okolicach Kuźnicy. Doświadczenia mieszkańców, mps pracy magisterskiej obronionej na Uniwersytecie w Białymstoku, 2006.

\section{Słowniki}

Uniwersalny słownik języka polskiego PWN. K-Ó, red. S. Dubisz, Warszawa 2006.

\section{Opracowania i artykuły}

Borowski P., Czy tylko genialny samouk?, „Gazeta Współczesna” 7 XI 1988.

Borucka-Arctowa M., Legalizm a konformizm i oportunizm, „Ruch Prawniczy, Ekonomiczny i Socjologiczny" 1964, nr 2.

Camus A., Człowiek zbuntowany, przeł. J. Guze, Warszawa 2002.

Danilecki T., Działania Służby Bezpieczeństwa wobec NSZZ "Solidarność" Regionu Białystok w latach 1980-1981, [w:] Początki "Solidarności" w pótnocno-wschodniej Polsce (1980-1981), red. T. Danilecki, Białystok 2005. 
Danilecki T., Beszta-Borowski Jan, [w:] Encyklopedia Solidarności. Opozycja w PRL 19761989, t. 1, red. M. Łątkowska, Warszawa 2010.

Danilecki T., Bakun Kazimierz, [w:] Encyklopedia Solidarności. Opozycja w PRL 19761989, t. 2, red. G. Waligóra, Warszawa 2012.

Danilecki T., Między Marcem a Sierpniem. Przykłady postaw opozycyjnych mieszkańców Białostocczyzny w końcu lat sześćdziesiątych i w latach siedemdziesiątych XX w., „Studia Podlaskie" 2018, t. XXVI.

Danilecki T., Między zaangażowaniem, przystosowaniem i sprzeciwem. Postawy mieszkańców województwa białostockiego wobec wyborów powszechnych w latach 1957-1969, Białystok-Warszawa 2019.

Kersten K., Terror na przełomie wojny i pokoju, „Aneks” 1988, nr 51-52.

Kietliński M., Jakub Antoniuk 1911-1988, [w:] Słownik biograficzny białostocko-łomżyński, z. 1, red. A. Dobroński et al., Białystok 2002.

Kietliński M., Jan Beszta-Borowski, [w:] Opozycja w PRL. Słownik biograficzny 1956-89, t. 1, red. J. Skórzyński, P. Sowiński, M. Strasz, Warszawa 2000.

Kietliński M., Niezależny Samorządny Związek Zawodowy Rolników Indywidualnych "Solidarność" w województwie białostockim w latach 1980-1981, [w:] Mój Kościół w historię wpisany. Księga pamiątkowa dedykowana Księdzu Profesorowi Tadeuszowi Krahelowi, red. T. Kasabuła, A. Szot, Białystok 2007.

Kietliński M., Szot A., Z dziejów rolniczej „Solidarności” w województwie białostockim 1980-1989. Niezależny Samorządny Zwiąek Zawodowy Rolników Indywidualnych "Solidarność" w świetle dokumentów archiwalnych, Białystok 2013.

Kula M., Niemota ubezwłasnowolnionych, „Pamięć i Sprawiedliwość” 2000, nr 1.

Markiewicz M., Kolektywizacja wsi w województwie białostockim 1948-1956, Białystok 2010.

Markiewicz M., Odwilż na prowincji. Białostocczyzna 1956-1960, Białystok-Warszawa 2019.

Mazur M., Antykomunistycznego podziemia portret zbiorowy 1945-1956. Aspekty mentalno-psychologiczne, Warszawa-Lublin 2019.

Mażewski L., Posttotalitarny autorytaryzm PRL 1956-1989. Analiza ustrojowopolityczna, Warszawa-Biała Podlaska, 2010.

Merton R. K., Teoria socjologiczna i struktura społeczna, przeł. E. Morawska i J. Wertenstein-Żuławski, Warszawa 2002.

Milewski J.J., Jakub Antoniuk (1911-1988), [w:] Abramowicz S. et al., Konspiracja i opór społeczny w Polsce 1944-1956. Słownik biograficzny, t. I, Kraków-Warszawa-Wrocław 2002.

Milewski J.J., Życie z kolcami, „Gazeta Współczesna” 10 X 1988.

Niemczuk A., Konformizm contra nonkonformizm, [w:] Niezależni i ulegli. Studia o nonkonformizmie, red. R. E. Bernacka, Torun 2008.

Nowak S., Pojęcie postawy w teoriach i stosowanych badaniach społecznych, [w:] Teorie postaw, red. S. Nowak, Warszawa 1973. 
Nowicka E., Świat człowieka - świat kultury. Systematyczny wykład problemów antropologii kulturowej, Warszawa 1997.

Partyzanckie ścieżki, red. H. Matejczyk, Białystok 1957.

Paszkiewicz J., O postawach konformizmu i nonkonformizmu, „Etyka” 1972, nr 10.

Postołowicz L., Jakub Antoniuk (1911-1988), „Białostocczyzna” 1989, nr 1.

Slezkine Y., Dom władzy. Opowieść o rosyjskiej rewolucji, t. 1: W drodze, przeł. G. Chodakowski-Gyurics et al., Warszawa 2019.

Studenci Warszawy. Studium długofalowych przemian postaw i wartości, red. S. Nowak, Warszawa 1991.

Sztompka P., Socjologia. Analiza społeczeństwa, Warszawa 2004.

Śleszyński W., Obóz odosobnienia w Berezie Kartuskiej 1934-1939, Białystok 2003.

Świda-Ziemba H., Człowiek wewnętrznie zniewolony, Warszawa 1998.

\title{
Publikacje internetowe
}

Choma-Jusińska M., Ośrodek Myśli Ludowej, http://www.encysol.pl/wiki/Ośrodek_ Myśli_Ludowej, [dostęp: 9 VI 2020].

\section{Between nonconformity and conformity; or on the various forms of resistance against authoritarian rule represented by the rural "Solidarność" leaders of the Podlasie region in the 1980s}

\begin{abstract}
Summary
The article, through examination of three opposition activists from the rural areas surrounding Białystok, investigates three distinct attitudes exhibited by nonconformist individuals functioning in an authoritarian country: opportunistic, rebellious, and strictly nonconformist. The research is based on concepts of conformity and nonconformity as defined by sociology, social psychology, and philosophy. The thesis of the article is that in order to understand and evaluate factors that govern a given individual's attitudes, one must first study their social, psychological and situational contexts of behavior at different stages of their lives.
\end{abstract}

Tomasz Danilecki - dr nauk humanistycznych, historyk, pracownik Muzeum Pamięci Sybiru w Białymstoku. W latach 2001-2018 pracował w Oddziale IPN w Białymstoku. Zainteresowania badawcze: postawy społeczne, aparat bezpieczeństwa w PRL, Polacy na Syberii w XIX i XX w.

e-mail: t.danilecki@poczta.onet.pl 